\title{
Research Paper Agricultural market intelligence center - A case
study of chilli crop price forecasting in Telangana
}

\author{
- R. Vijaya Kumari, Panasa Venkatesh, G. Ramakrishna and A. Sreenivas
}

See end of the paper for authors' affiliations

Correspondence to :

R. Vijaya Kumari

Department of Agricultural

Economics (A.M.I.C.),

College of Agriculture,

Professor Jayashankar

Telangana State Agricultural

University, Hyderabad

(Telangana) India

Paper History :

Received : 03.07.2019;

Revised : 13.07.2019;

Accepted : 14.08 .2019
ABSTRACT : Indian is an agriculture based country, where more than 50 per cent of population is depend on agriculture. This structures the main source of income. The commitment of agribusiness in the national income in India is all the more, subsequently, it is said that agriculture in India is a backbone for Indian Economy. The majority of the rural producers are unable to understand and interpret the market and price behaviour to their advantages. Hence, market information and intelligence are crucial to enable farmers and traders to make informed decisions about what to grow, when to sell, and where to sell. The price forecasts are made by analyzing the prices of agricultural commodities concerned over 17 years using advanced statistical tools like ARIMA, ARCH, GARCH models, comparing the same with prices of futures markets and national and international reports of trade surveys besides conducting state level trade surveys. Under the project price forecasts were made for chilli twice once during Kharif season for 2 years from Kharif 2017-18 and 2018-19. Thus, out of total 4 price forecasts 3 price forecasts with more than 90 per cent precision were developed and disseminated through various means like university website, university magazine "Vyavasayam", SMS to contact farmers, All India radio, farmers' trainings and meetings, etc.

KEY WORDS : Agricultural market, Intelligence center, Chilli crop

How To Cite This PAper : Kumari, R. Vijaya, Venkatesh, Panasa, Ramakrishna, G. and Sreenivas, A.(2019). Agricultural market intelligence center - A case study of chilli crop price forecasting in Telangana. Internat. Res. J. Agric. Eco. \& Stat., 10 (2) : 257-261, DOI : 10.15740/HAS/IRJAES/10.2/257-261. Copyright@ 2019: Hind Agri-Horticultural Society. 